Yurtbakan, E. ve Erdoğan, T. (2020). İlkokul 4. sınıf öğrencilerinin okuma alışkanlıklarının belirlenmesi: Bir karma yöntem. Ana Dili Eğitimi Dergisi, 8(2), 240-257.

Ana Dili Eğitimi Dergisi
Journal of Mother Tongue Education
www.anadiliegitimi.com
Geliş/Received: 26.10 .2019 Kabul/Accepted:03.02.2020
Araştırma Makalesi / Research Paper

\title{
İlkokul 4. Sınıf Öğrencilerinin Okuma Alışkanlıklarının Belirlenmesi: Bir Karma Yöntem*
}

\author{
Ergün YURTBAKAN** \\ Tolga ERDOĞAN ${ }^{* * *}$
}

\begin{abstract}
Öz
Bu araştırmanın amacı; ilkokul 4. sınıf öğrencilerinin okuma alışkanlıklarını belirlemektir. Araştırma, karma yöntemin gömülü (içeyerleşik) araştırma desenine dayanmaktadır. Nicel araştırmaya dayanan ilk kısma, Trabzon ili Maçka ilçesinde bulunan beş ilkokulda 4. sınıfta okuyan 243 öğrenci katılmıştır. Bu öğrencilerin amaçlı örneklem yoluyla seçilen 15 velisinin ve 15 öğretmeninin katıldığı, görüşmelere dayanan nitel yöntem ile de nicel bulgular açıklanmaya çalışılmıştır. Bu çalışmada veri toplama aracı olarak nicel kısımda 25 sorudan oluşan anket, nitel kısımda ise, nitel araştırma metotları içerisinde sıkça kullanılan yarı yapılandırıımış görüşme ve görüşme formu kullanılmıştır. Araştırmanın nicel boyutunda elde edilen veriler SPSS 23.0 programı ile analiz edilmiş, analiz sonuçları frekans ve yüzde olarak gösterilmiştir. Araştırmanın nitel boyutunda; 7 öğretmenden yarı yapılandırılmış görüşme, 8 öğretmen ve 15 veliden görüşme formu yoluyla elde edilen veriler betimsel analizle analiz edilmiştir. Çalışma sonunda, ilkokul öğrencilerinin her gün düzenli kitap okumalarına rağmen yeterli sayıda kitap okumadıkları sonucuna ulaşıımıştır. Öğrencilerin tür olarak en çok hikaye, konu olarak da macera kitaplarını tercih ettikleri görülmüştür. Öğrencilerin kitapları seçerken en çok konusuna dikkat ettikleri, kitap dışında en çok dergi okumayı tercih ettikleri, okuyacakları kitapları anne ve babalarıyla aldıkları, kütüphaneyi hikaye ve roman almak için kullandıkları tespit edilmiştir. Öğrencilerin okumalarına televizyonun engel olduğu ortaya çıkmıştır.
\end{abstract}

Anahtar Kelimeler: İlkokul öğrencileri, okuma alışkanlıkları, aileler

\section{Determining Reading Habits of Fourth Grade Elementary School Students: A Mixed Methods Desing}

\begin{abstract}
The purpose of this research is to determine the reading habits of the 4th grade students in primary school. The research is based on the embedded (covering) research pattern of the mixed method. The first part based on quantitative research was attended by 243 students studying in 4th grade in five primary schools in Maçka District of Trabzon province. Quantitative findings were tried to be explained by the qualitative method based on the interviews of 15 parents and 15 teachers selected by the purposeful sampling of these students. In this study, a questionnaire consisting of 25 questions in the quantitative part and the semi-structured interview and interview form, which are frequently used in the qualitative research methods, were used in the qualitative part. . The data obtained in the quantitative dimension of the research were analyzed with the SPSS 23.0 program, the analysis results are shown in frequency and percentage. In the qualitative dimension of the research, the data obtained through 7 semi-structured interviews, 8 teachers and 15 parents
\end{abstract}

\footnotetext{
* Makale Ergün Yurtbakan tarafından yazılan “ilkokul 4. sınıf öğrencilerinin okuma alışkanlıklarının belirlenmesi” isimli tezden üretilmiştir.

** Doktora öğrencisi, Trabzon Üniversitesi, Fatih Eğitim Fakültesi, Sınıf Öğretmenliği Bölümü, Trabzon, gamsiz6436@gmail.com, ORCID: 0000-0001-8811-6320

*** Prof. Dr., Trabzon Üniversitesi, Fatih Eğitim Fakültesi, Sınıf Öğretmenliği Bölümü, Trabzon, tolgaerdugan.edu@gmail.com, ORCID:0000-0001-9102-4646
} 
interview forms were analyzed with descriptive analysis. At the end of the study, it was concluded that elementary school students did not read a sufficient number of books despite reading books regularly every day. It was understood that the students preferred the most story type for reading books, and books on adventure topics. It was determined that the students pay attention to the topic while choosing the books, they prefer to read magazines outside the book, they buy the books with their parents and use the library to buy stories and novels. It was revealed that television was an obstacle to students' reading.

Keywords: Primary school students, reading habits, families

\section{Giriş}

Okuyucu ile yazar arasında etkileşime dayanan, belli bir amaç doğrultusunda uygun bir yöntemle ön bilgilerin kullanılarak, tertipli bir ortamda gerçekleştirilen anlam kurma süreci olan okuma (Akyol, 2013), kişilerin kendilerini doğru ve daha iyi ifade etmesini sağladığı gibi (Ender Durualp, Çiçekoğlu ve Enver Durualp, 2013; Sukhram ve Hsu, 2012), boş vakitlerini değerlendirmelerine; kültürel, ekonomik ve teknolojik ilerlemeleri izlemelerine, yeni bilgiler öğrenmelerine, okul ve sosyal hayatta başarılı olmalarına yardımcı olur (Aksaçlıoğlu ve Yılmaz, 2007).

Yaşamımıza yavaş yavaş giren, bilinçsiz veya bilinçli tekrarlanması ile derinleşen, bırakılmadığı takdirde ihtiyaç haline gelen davranışlara alışkanlık (Aksaçlıoğlu, 2005; Yıldız, 2013), okuma eyleminin; insanlar tarafından bir intiyaç gibi algılanıp, ömür boyu, devamlı ve düzenli şekilde tekrarlanmasına ise okuma alışkanlığı denir (Can, Türkyılmaz ve Karadeniz, 2010). Yaşı küçük çocuklarda daha çabuk kazanılan bu alışkanlığın (Ronkova ve Wildova, 2015), ilkokul döneminde kazandırılmadığı takdirde, sonraki dönemlerde kazandırılması güçleşmektedir (Sangkaeo, 1999). Bireylerin okuma alışkanlığını kazanıp kazanmadığını anlamak için okudukları yayın türüne, bu türleri hangi oranda ve ne sıklıkta okuduklarına, bir kerede aralıksız ne kadar okuduklarına; günün, haftanın, ayın hangi zamanlarında okuduklarına, okudukları kitapları nasıl elde ettiklerine ve hangi stratejileri kullanarak okuduklarına bakılabilir (Dökmen, 1994).

Okuma alışkanlığının kazandııımasından öncelikle çocuğun ailesi, sonra okulu ve öğretmeni, en sonda ise yaşadığı toplum sorumludur (Gürcan, 1999). Aileler bu sorumluluğu; okul öncesi dönemde kitapların resimlerini inceleyerek (Marlow, 1992), okumanın önemi hakkında konuşarak (McCarty ve diğ., 2001), çocuklarını kitaplarla buluşturarak, çocuklarına bilinçli kitap seçme becerisi kazandırarak (Yağcı, 2007), boş zamanlarında gazete, kitap, dergi vb. okuyup onlara model olarak yerine getirebilirler (Inan, 2005).

Okuma kültürü yeteri kadar gelişmemiş ailelerin çocuklarına okuma alışkanlığı; gerek okuma öğretiminde gerekse okumanın geliştirilmesinde farklı ve yaratıcı teknikler kullanan öğretmenler tarafından çocuklara okuma ile ilgili sorumluluk görevleri vermeleri ile kazandırılabilir (Aşılıoğlu, 2006; Batur, Gülveren ve Bek, 2010; Sağlam, Suna ve Çengelci, 2008; Stanfield, 2006). Fakat öncelikle öğretmenlerin bu alışkanlığa sahip olması gerekmektedir (Kurulgan ve Çekerol, 2008). Çünkü çocuğun çevresinde kitap okumayı seven, kitap okuyan veya kitap hakkında konuşan birileri olduğunda okumaya olan ilgisi artar (Ronkova, Wildova, 2015). Bunun yanında öğretmenler, öğrencileri kitap okuduğunda ödüllendirebilir ve onları herhangi bir dergiye abone edebilir, onların okuyacakları kitapları seçmelerine müsaade edebilir (İşcan, Arıkan, Küçükaydın, 2013; Suna, 2006). Bu yüzden sınıflarında veya okullarında kütüphaneler kurup, öğrenme araçları ve teknoloji ile okuma etkinliklerini destekleyerek okuldaki gerekli okuma konforunu sağlayabilir (Mugambi, 2015). Bu fiziksel düzenlemeler sayesinde öğrenciler düzenli olarak kütüphaneleri kullanacak, öğrencilerin okuma ilgi ve tutumları artacak böylece öğrenciler okuma alışkanlığı kazanacaktır (Oyelude, 2013; Özbay, 2006). Gerek bu uygulamaların ya da düzenlemelerin doğru yapılmaması gerekse de yanlı̧̧ arkadaş seçimi, arkadaşlarla geçirilen vaktin doğru ayarlanamaması okuma alışkanlığını olumsuz etkilemektedir (Demirer ve diğerleri, 2010). Buna ilaveten sınıflarda kitaplıkların, okullarda kütüphanelerin olmayışı, var olanların ise ihtiyacı karşılamaması da okuma alışkanlığını olumsuz etkilemektedir (İnan, 2005). Hatta tv, vcd, radyo, bilgisayar, internet gibi hızla gelişen ve değişen teknolojik ürünler de okuma alışkanlığını olumsuz yönde etkileyebilmektedir (Aksaçlıoğlu ve Yılmaz, 2007; Balcı, 2009; Mokhtari, Reichard ve Gardiner, 2009). 
Literatür incelendiğinde; ilkokul öğrencilerinin okuma alışkanlıklarını engelleyen etmenleri belirlemeye yönelik nicel çalışmaların (Mokhtari, Reichard, ve Gardner, 2009), okuma alışkanlıklarını belirlemeye yönelik ise hem nicel hem de nitel çalışmaların olduğu (işscan, Arıkan ve Küçükaydın, 2012; Mugambi, 2015; Nasser, 2013; Smaragdi ve Jönsson, 2006; Şahin, 2012; Uusen ve Müürsep, 2012) fakat nitel ve nicel çalışmaları içine alan herhangi bir karma çalışmanın olmadığı, bunun da literatürde önemli bir eksiklik olduğu görülmektedir. Karma yöntemden yararlanılan bu çalışmada ise; öğrencilerin okuma alışkanlıklarının düzeylerinin belirlenecek olması, ailelerinin ve öğretmenlerinin, öğrencilere okuma alışkanlığı kazandırmadaki rolleri hakkında görüşlerinin alınması; başka aile ve öğretmenlere yol gösterecek olması nedeniyle araştırma önem taşımaktadır. Ayrıca okuma alışkanlığının, ilköğretim düzeyinde gerçekleşiyor olması (Güneş, 2007) sebebiyle, ilkokulların bu alışkanlığı kazandırmada ne kadar başarılı olabildiklerinin görülecek olması araştırılmanın gerekliliğini ortaya koymaktadır. Bu yüzden de araştırmaya ilkokulun son dönemi olan 4. sınıf öğrencileri seçilmiştir ve bu öğrencilerin okuma alışkanlıkları belirlenmeye çalışımıştır. Araştırmada bu amaca ulaşmak için aşağıdaki sorulara yanıt aranmıştır:

1. İlkokul 4. sınıf öğrencilerinin kitap okuma alışkanlıkları profili (Düzenli kitap okuma alışkanlıklarının düzeyi, ders kitabı dışında kitap okuma sıklıkları, ders kitabı dışındaki kitap sayıları, son 1 yılda ders kitabı dışında okudukları kitap sayısı, öğrencilerin anne ve ya babalarının kitap okuma alışkanlıkları) ne düzeydedir?

2. İlkokul 4. sınıf öğrencilerinin okuma tercihleri (Okudukları kitap türü, okudukları kitapların konuları, kitap seçerken dikkat ettikleri özellikler, kitaptan başka okudukları yayınlar) nelerdir?

3. İlkokul 4. sınıf öğrencilerinin ders kitapları dışında okuma kitaplarına ulaşma durumları ve kütüphane kullanma amaçları nelerdir?

4. İlkokul 4. sınıf öğrencilerinin kitap okumalarını olumsuz etkileyen faktörler (Ev işleri, kitap fiyatlarının pahalı olması, ödevlerin çokluğu, televizyon, evde çalışma ortamının olmaması, arkadaşlarıyla görüşmek) nelerdir?

5. Öğretmenlerin öğrencilerinin okuma alışkanlıklarına ilişkin görüşleri nelerdir?

6. Velilerin Çocuklarının okuma alışkanlıklarına ilişkin görüşleri nelerdir?

\section{Araştırmanın Modeli}

\section{Yöntem}

İlkokul 4. Sınıf öğrencilerinin okuma alışkanlıklarını belirlemek amacıyla yapılan çalışmada karma yöntemin gömülü deseninden yararlanılmıştır. Nicel ve nitel yöntemlerin birlikte kullanıldığı karma yöntemin gömülü deseninde, verilerin çoğunluğu nitel veya nicel bir araştırmadır fakat verilerin desteklenmesi için alternatif yöntemlerden elde edilecek verilere ihtiyaç duyulmaktadır (Yıldırım ve Şimşek, 2013). Bu bağlamda, araştırmada ilkokul 4. sınıf öğrencilerinin okuma alışkanlıklarını belirleyebilmek için elde edilen verilerin çoğunluğu öğrencilere uygulanan anketten elde edilmiş olup, bu verileri desteklemek için öğretmenlerle yarı yapılandırımış görüşmeler yapılmış, velilere de yarı yapılandırılmış görüşme formu dağıtılmıştır.

\section{Örneklem / Araştırma grubu}

Araştırmanın evrenini 2016-2017 eğitim-öğretim yılında Trabzon ili Maçka ilçesinde beş farklı ilkokulda okumakta olan 243 ilkokul 4. sınıf öğrencisi oluşturmaktadır. Araştırmaya hız kazandırmak ve öğrencilere kolay ulaşabilmek için amaçlı örnekleme yönteminin kolay ulaşılabilir durum örneklemesi yolu ile öğrenciler seçilmiştir. Kolay ulaşılabilir durum örneklemesi; araştırmaya hız ve pratiklik kazandırır ve araştırmacı, yakın olan ve erişilmesi kolay olan bir durumu seçer (Yıldırım ve Şimşek, 2013).

Öğrencilerin; \%50.60’ı (123) kızlardan, \% 49.40'ı (120) erkeklerden oluşmaktadır. Öğrenci ailelerinin gelir düzeyine bakıldığında; \%42.00'sinin 751-1500 TL, \%21.00'inin 1501-2250 TL, \%10.30'unun 2251-3000 TL ve \%7.50'sinin 3000 TL gelire sahip olduğu görülmektedir. Bu da öğrenci ailelerinin çoğunun düşük gelir düzeyine sahip olduğu sonucunu ortaya çıkarmaktadır. Öğrencilerin anne babalarının kitap okuma sıklıklarına bakıldığında; yarısına yakınının (\% 49.80) ara sıra, çeyreğinden fazlasının (\% 32.50) hiç kitap okumadığı, az bir kısmının (\%11.10) genellikle, çok azının 
(\%6.60) ise her zaman kitap okuduğu ortaya çıkmıştır. Öğrencilerin kendilerine ait odaları incelendiğinde; yarısından çoğunun (\% 68.30) odasının olduğu, bilgisayara sahip olmalarına bakıldığında çoğunun (\%60.90) bilgisayar sahibi olduğu, evlerinde internet bağlantısı olup olmama durumlarına bakıldığında ise yarıdan fazlasının (\%53.90) evinde internet bağlantısı olduğu görülmektedir. Öğrencilerin $58^{\prime}$ inin (\%45.70) bilgisayar ve internette zaman geçirmediği, 25'inin (\%19.70) haftada 1-2 saat, $28^{\prime}$ inin (\%22.00) günde 1 saat, 7 'sinin (\%5.50) günde 2 saat, $5^{\prime}$ inin (\%3.90) günde 3 saat, 2'sinin (\%1.60) günde 3-4 saatten fazla bilgisayar ve internette zaman geçirdiği görülmektedir. İnterneti kitap okuma amaçlı kullanma durumlarına bakıldığında; öğrencilerin 41'inin (\%32.30) interneti kitap okuma amaçlı kullandığı, 86'sının (\%67.70) kitap okuma amaçlı kullanmadığı ortaya çıkmıştır.

Araştırmaya katılan öğretmenlerin 7'si erkek, 8'i kadındır. Bunun yanında öğretmenlerin 12 'sinin lisans, 3 'ünün eğitim enstitüsü mezunu olduğu ve bu öğretmenlerin 11'inin sınıf öğretmenliği, 4'ünün farklı programlardan (okulöncesi, tarih, peyzaj mimari, meslek dersleri öğretmeni) mezun olduğu görülmektedir. Ayrıca öğretmenlerin 7'sinin Karadeniz Teknik Üniversitesinden, geri kalanlarının farklı üniversitelerden (Gümüşhane Mareşal Fevzi Çakmak ve Giresun Eğitim Enstitüsü, Gazi Osmanpaşa, Ağrı İbrahim Çeçen, Hacettepe, Niğde, Atatürk Üniversitesi) mezun oldukları görülmektedir. Öğretmenlerin meslekte çalışma sürelerinin ise çoğunlukla 10 ile 20 yıl arasında değiştiği görülmektedir.

Araştırmaya katılan veliler de öğretmen tarafından okula çağııılığında hemen gelebilecek olanlar arasından seçilmiştir. Kolay ulaşılabilir durum örneklemesi ile seçilen velilerin 12'si kadın, 3'ü erkektir. Velilerin 6'sı ilkokul, 2'si ortaokul, 2'si lise ve 5'i lisans mezunudur. Velilerin 9'u ev hanımı 4'ü memur, 1'i serbest meslek sahibi ve işçidir. Velilerin 6'sı her gün kitap okurken, 9'u ara sıra kitap okumaktadır.

\section{Veri Toplama Araçları}

Araştırmada ilkokul 4. Sınıf öğrencilerinin okuma alışkanlıklarını belirlemek amacıyla Demirer ve diğerleri (2010) tarafından geliştirilen "ilköğretim Öğrencilerinin Kitap Okuma Profil ve Eğilimlerini Belirleme Anketi" kullanılmıştır. Veri toplama aracının birinci bölümünü oluşturan "Kişisel Bilgiler" bölümünde çalışmaya katılan ilköğretim öğrencilerini tanımayı sağlayacak; bazı değişkenler, okuma profilleri ve eğilimleri ile ilişkilendirilecek bilgileri elde etmeye yarayan maddeler yazılmıştır. Bu kapsamda cinsiyete, yerleşim yerine, aylık gelire, anne ve babanın kitap okuma durumuna ilişkin sorular hazırlanmıştır. Anket, bütün bu özellikleri belirlemeye yönelik 35 sorudan oluşmuştur. Araştırmanın amacıyla örtüşmesi ve kapsam geçerliliğini sağlamak için üç konu alanı uzmanının görüşü alınarak 11 soru çıkartılmış, kalan 24 soruluk anket ilkokul 4. Sınıf öğrencilerine uygulanmıştır.

Anketi uygulamak için Demirer ve diğerlerinden (2010) izin alınmıştır. İzin alındıktan sonra anket 243 öğrenciye uygulanmıştır. Ayrıca araştırmada öğrencilerin okuma alışkanlıklarını belirlemek için öğrencilerin 7 öğretmeniyle yarı yapılandırılmış görüşme yapılmış, diğer 8 öğretmene ise görüşme formu dağıtılmıştır. İki bölümden oluşan yarı yapılandırılmış görüşme aracının birinci kısmında araştırmaya katılan öğretmenleri tanımaya yönelik 5 soru, ikinci kısımda öğrencilerin okuma alışkanlıkları hakkındaki düşüncelerini belirlemeye yönelik 6 soru bulunmaktadır. Hazırlanan görüşme sorularıyla ilgili üç konu alanı uzmanının görüşü alınmıştır. Konu alanı uzmanlarının önerileriyle sorulara 2 soru daha eklendikten sonra görüşme formuna son şekli verilmiştir. Toplam 13 sorudan oluşan veri toplama aracı ile öğretmenlerle yarı yapılandırılmış görüşmeler yapılmıştır. Yarı yapılandırılmış görüşme için hazırlanan soruların aynısı görüşme teklifini kabul etmeyip, görüşme formunu doldurmayı kabul eden öğretmenlere doldurmaları için verilmiştir. Çocuklarının okuma alışkanlıkları hakkındaki düşüncelerini belirlemek için velilere dağıtılan görüşme formu da iki kısımdan oluşmaktadır. Birinci kısımda öğrenci velilerini tanımaya yönelik olarak 5 soru, ikinci kııımda ise öğrencilerin okuma alışkanlıklarını belirlemeye yönelik 6 soru bulunmaktadır. Sorular hazırlanırken üç konu alanı uzmanının görüşü alınmıştır. Konu alanı uzmanlarının önerileriyle sorulara 2 soru daha eklendikten sonra 13 sorudan oluşan görüşme formu, doldurmaları için velilere dağıtılmıştır. 


\section{İşlem / Verilerin Toplanması}

Araştırmaya ilişkin uygulamalar 2016-2017 öğretim yılı ekim ayının ilk iki haftasında örneklem grubunda belirlenen beş ilkokula gidilerek yapılmıştır. Araştırmada kullanılan anket ve görüşme sorularının uygulanması için Trabzon Milli Eğitim Müdürlüğünden izin alınmıştır. Anketler çoğaltılıp, okulda sınıf öğretmenlerin rehberliğinde öğrenciler tarafından cevaplandııımıştır. Anketteki sorular, her sınıfın kendi öğretmeni rehberliğinde öğrencilere doldurtulmuştur. Bütün öğretmenler, sınıflarındaki öğrencilere anketi doldurturken soruları teker teker okumuş, gerekli açıklamaları yapmış, daha sonra öğrencilerden kendilerine uygun olan cevabı işaretlemelerini istemiştir. Bu haliyle anketin doldurulması yaklaşık 20 dakika sürmüştür.

Öğretmenlerin 7 tanesi ile yarı yapılandırılmış görüşme yapılmıştır. Öğretmenlere, görüşmelerin ses-kayıt cihazı ile kayıt altına alınacağı söylenmiş, gönülülük ilkesine göre kendilerinden izin alınmıştır. Görüşmeler dersleri aksatmamak için öğle arasında ve okul çıkısında yapıımıştır. Her görüşme yaklaşık 10 dakika, toplamda yaklaşık 70 dakika sürmüştür. Elde edilen bu veriler yazıya geçirilip, düz metin haline getirilmiştir. Diğer 8 öğretmen ise ses kayıt cihazını kabul etmemiş olmasına rağmen görüşme formunu doldurmayı kabul etmişler ve kendilerine verilen görüşme formundaki soruları yaklaşık 5 dakika içinde doldurmuşlardır.

Velilerle ise sınıf öğretmeni aracılığıyla randevu alınmış, önceden hazırlanmış görüşme formu randevu saatinde velilere gönüllülük ilkesine dayalı olarak doldurtulmuştur.

\section{Verilerin Analizi}

Öğrencilerinin demografik özellikleri, kitap okuma alıskanlıkları profillleri, öğrencilerin okuma tercihleri, öğrencilerin ders dışında okuma kitaplarına ulaşma durumları ve kütüphane kullanma amaçları, öğrencilerin kitap okumalarını olumsuz etkileyen faktörleri belirleyebilmek amacıyla yapılan analizde yüzde ve frekans tekniği kullanılmıştır. Bu veriler SPSS 23.0 programıyla analiz edilmiştir.

Öğrenci velileri ve öğretmenleri ile yapılan yarı yapılandırılmış görüşmelerden elde edilen veriler, betimsel analiz ile analiz edildikten sonra hangi sıklıkta tekrar edildiğine bakılmış ve görüşmelerden doğrudan alıntılar yapılmıştır. Aynen alıntılar yapılırken görüşme yapılan her öğretmene bir numara verilerek "(Kadınlara K, numara; Erkeklere E, numara)" şeklinde kodlanmıştır.

\section{Bulgular}

Araştırmanın bu bölümünde; öğrencilerin kitap okuma alışkanlıkları profillleri, okuma tercihleri, ders dışında okuma kitaplarına ulaşma durumları ve kütüphane kullanma amaçları, kitap okumalarını olumsuz etkileyen faktörler ile veli ve öğretmenlerinin görüşlerinden elde edilen verilere yer verilmiştir.

\section{İlkokul 4. Sınıf Öğrencilerinin Kitap Okuma Alışkanlığı Profili}

Araştırmanın nicel kısmında ilkokul 4. Sınıf öğrencilerinin düzenli kitap okuma alışkanlıkları, ders kitabı dışında kitap okuma sıklıkları, son 1 yılda ders kitabı dışında okudukları kitap sayıları, öğrenci anne ve babalarının kitap okuma alışkanlığı hakkında; nitel boyutunda ise, öğretmenlerin öğrencilerine okuma alışkanlığı kazandırmada yaptıkları etkinlikler ve bu etkinliklerin yeterliliği, sınıflarındaki okumayı seven öğrenci sayıları ve okumayı sevmelerinde etkili olan faktörler hakkında bilgi edinilmeye çalışımıştır.

Öğrencilerin büyük çoğunluğunun (\%80.20) düzenli kitap okuduğu, geri kalanının (\%19.80) ise düzenli kitap okumadığı görülmektedir.

Öğrencilerin ders kitapları dışında düzenli olarak kitap okuma sıklıklarına bakıldığında; birinci sırada düzenli olarak her gün (\%37.90), ikinci sırada haftada 2-3 gün (\%36.60), üçüncü sırada haftada bir gün (\%10.70), dördüncü sırada ayda bir veya birkaç gün kitap okuyanların (\%9.50), beşinci sırada kitap okumayanların (\%3.70), en sonda ise sadece şubat ve yaz tatillerinde kitap okuyanların (\%1.60) yer aldığı görülmektedir. Bu bağlamda öğrencilerin çoğunlukla kitap okudukları sonucuna ulaşılabilir.

Öğrencilerin ders kitabı dışındaki kitap sayılarına bakıldığında; \%48.6'sının 10 ve daha az adette, \%38.7'sinin 11-50 adet, \%8.20'sinin 51-100 adet kitaba, \%4.5'inin ise 101'den fazla kitaba sahip olduğu ortaya çıkmıştır. Bu sonuçla birlikte öğrencilerin yeteri kadar kitaba sahip olmadığı söylenebilir. 
Öğrencilerin son bir yılda ders kitabı dışında okudukları kitap sayılarına bakıldığında; bir yılda en fazla 6-10 (\%28.40) kitap okuyanların birinci sırada, 1-5 (\%23.00) kitap okuyanların ikinci sırada, 2150 (\%16.50) kitap okuyanların üçüncü sırada, 51'den fazla (\%15.60), 11-20 (\%13.60) kitap okuyanların beşinci sırada yer aldığı tespit edilirken, en son sırada kitap okumayanların (\%2.90) yer aldığı tespit edilmiştir.

Öğrencilerin anne babalarının kitap okuma sıklıklarına bakıldığında; anne babaların neredeyse yarısının (\%49.80) ara sıra kitap okuduğu, bunları hiç kitap okumayanların (\%32.50) takip ettiği, sonra genellikle (\%11.10) okuyanların geldiği, en sonda ise her zaman (\%6.60) kitap okuyanların yer aldığı ortaya çıkmıştır. Bu sonuçtan yola çıkarak velilerin yeteri kadar okuyucu olmadıkları söylenebilir.

\section{ilkokul 4. Sınıf Öğrencilerinin Okuma Tercihleri}

Araştırmanın bu bölümünde; Illkokul 4. Sınıf öğrencilerinin hangi tür ve konuyu içeren kitaplar okudukları, kitap seçerken nelere dikkat ettikleri, kitaptan başka hangi tür yayınlar okudukları sunulmaktadır.

Öğrencilerin tercih ettikleri kitap türlerine ilişkin bulgular incelendiğinde, öğrencilerin en çok öykü türünü (\%36.20) tercih ettikleri görülmektedir. Bu türden sonra öğrenciler en çok çizgi roman türündeki kitapları (26.00) tercih etmektedirler. Öğrencilerin tercih ettikleri diğer türler ise sırasıyla şiir (\%20.50), roman (\%14.20) ve diğer \%(3.10) şeklindedir.

İlkokul 4. sınıf öğrencilerinin büyük bir kısmı (\%70.80) macera içerikli kitapları okumayı tercih etmektedirler. Bu tercihten sonra öğrencilerin sırasıyla duygusal içerikli (\%11.10), kahramanlık ve tarih içerikli (\%5.80), mizah içerikli (\%4.10), bilim kurgu (\%3.70), toplumsal konu (\%2.50) ve en sonda da diğer (\%2.10) içerikli kitapları tercih ettikleri görülmektedir. Bu bulgulara dayanarak bilim kurgu, mizah ve toplumsal içerikli kitapların çok az tercih edildiği söylenebilir.

Öğrencilerin kitaptan başka okudukları yayınları belirleyebilmek amacıyla öğrencilere birden fazla seçim hakkı verilmiştir. Bunun sonucunda da öğrencilerin çoğunun (\%38.20) dergi, sonra çizgi roman $(\% 31.20)$, daha sonra gazete $(\% 20.30)$, son olarak da diğer yayınları (\%10.30) okudukları tespit edilmiştir.

Öğrencilerin kitap tercihlerini belirleyebilmek amacıyla öğrencilere birden fazla seçim hakkı verilmiştir. Bunun sonucunda da öğrencilerin kitap seçerken en çok konusuna (\%22.50), sonra sırası ile fiyatına (\%15.20), öğretmen önerisine (\%13.20), resimli olmasına (\%12.30), kitabın kalınlığına (\%12.00), yazarına (\%9.40), kapağına (\%7.90), arkadaş önerisine (\%5.50), en sonda ise diğer (\%2.00) özelliklerine dikkat ettikleri belirlenmiştir. Bu sonuçlardan öğrencilerin kitap seçerken öncelikle kendi kıstaslarını dikkate aldıklarına ulaşılabilir.

\section{illkokul 4. Sınıf Öğrencilerinin Ders Kitabı Dışında Okuma Kitaplarına Ulaşma Durumları}

Araştırmanın bu bölümünde; illkokul 4. sınıf öğrencilerinin okudukları kitapları nasıl temin ettikleri, kütüphaneden ne amaçla yararlandıkları belirlenmiştir.

Öğrencilerin ders kitapları dışında okuma kitaplarına ulaşma durumlarını belirlemek amacıyla öğrencilere birden fazla seçim hakkı verilmiştir. Bu seçimlerin sonucunda; öğrencilerin \%22.6'sına anne-babalarının kitap aldığı, \%20.3'ünün anne-babalarıyla birlikte gidip kitapları kendilerinin seçtiği, \%18.30'unun okul kütüphanesi ya da sınıf kitaplığından aldığı, \%13.10'una hediye geldiği, \%11.30'unun harçlığı ile satın aldığı, \%5.80'inin arkadaşlarından ödünç aldığı, \%4.6'sının halk kütüphanelerinden aldığı, \%4.00'ünün diğer yollardan temin ettiği belirlenmiştir.

Öğrencilerin kütüphaneleri kullanma amaçları incelendiğinde; öğrencilerin \%60.90’ının kütüphaneye roman ve hikaye almak, \%18.90'ının ödev için ansiklopedi ve kitaplara bakmak amacıyla, \%16.50'sinin diğer amaçla gittiği görülürken, \%3.70'inin kütüphaneye gitmediği tespit edilmiştir.

\section{İlkokul 4. Sınıf Öğrencilerinin Kitap Okumalarını Olumsuz Etkileyen Faktörler}

Araştırmanın bu bölümünde; öğrencilerin kitap okumalarını genel olarak olumsuz etkileyen faktörler belirlenmiştir ve öğrencilerin okumalarına engel olan durumlar Tablo 1'de gösterilmiştir. 
Tablo 1.

Ögrrencilerin Kitap Okumasına Engel Durumlar

\begin{tabular}{|c|c|c|c|c|}
\hline Engeller & Frekans-Yüzde & Engel Oluyor & Kısmen Engel Oluyor & Engel Olmuyor \\
\hline \multirow{2}{*}{ Ev işleri } & Frekans & 54 & 38 & 151 \\
\hline & Yüzde & $\% 22.20$ & $\% 15.60$ & $\% 62.10$ \\
\hline \multirow{2}{*}{$\begin{array}{l}\text { Kitap Fiyatlarının Pahalı } \\
\text { Olması }\end{array}$} & Frekans & 37 & 82 & 124 \\
\hline & Yüzde & $\% 15.20$ & $\% 33.70$ & $\% 51.00$ \\
\hline \multirow{2}{*}{ Ödevlerin Çokluğu } & Frekans & 64 & 62 & 117 \\
\hline & Yüzde & $\% 26.30$ & $\% 25.50$ & $\% 48.10$ \\
\hline \multirow{2}{*}{ Televizyon } & Frekans & 105 & 60 & 78 \\
\hline & Yüzde & $\% 43.20$ & $\% 24.70$ & $\% 32.10$ \\
\hline Evde Çalışma & Frekans & 83 & 30 & 130 \\
\hline Ortamının Olmaması & Yüzde & $\% 34.20$ & $\% 12.30$ & $\% 53.50$ \\
\hline \multirow{2}{*}{ Arkadaşlarla Görüşmek } & Frekans & 60 & 47 & 136 \\
\hline & Yüzde & $\% 24.70$ & $\% 19.30$ & $\% 56.00$ \\
\hline
\end{tabular}

Öğrencilerin kitap okumalarına engel olan durumlar incelendiğinde; ev işlerinin, ödev çokluğunun ve kitap fiyatlarının pahalı olmasının öğrencilerin kitap okumalarına engel olmadığı görülmektedir. Televizyonun ise öğrencilerin kitap okumalarına engel olduğu görülmektedir.

Öğrencilerin yarısından fazlasının evinde çalışma ortamının olmamasının kitap okumalarına engel olmadığı görülürken, neredeyse üçte birine engel olduğu görülmektedir. Bunun yanında öğrencilerin yarııından fazlasında arkadaşlarıyla görüşmelerinin onların kitap okumalarına engel olmadığı görülürken, çok az bir kısmında engel olduğu görülmektedir.

\section{Öğretmenlerin, Öğrencilerinin Okuma Alışkanlıklarına İlişkin Görüşlerine Ait Bulgular}

Araştırmanın bu bölümünde; öğretmenlerin, öğrencilerine okuma alışkanlığı kazandırmak amacıyla yaptıkları çalışmalara ve öğrencilerinin okumayı sevmelerine etki eden etkenlere ilişkin görüşleri belirlenmiştir. Ayrıca öğretmenlerin sınıflarında kitaplıklarııın olup olmadığı ve kitaplıktaki kitapları nasıl temin ettikleri, okullarında kütüphane olup olmadığı ve kütüphaneyi hangi sıklıkta kullandıkları belirlenmeye çalışılmıştır. Bunun yanında öğrencilerinin okumayı sevmemelerine neden olan etkenlere ilişkin öğretmen görüşleri belirlenmiştir.

Öğretmenlere, öğrencilerine okuma alışkanlı̆̆ı kazandırmaya yönelik yaptıkları etkinlikleri yeterli görme durumları ve bu amaca yönelik yaptıkları çalışmaların neler olduğu sorulmuş; öğretmenlerden 9'u öğrencilerine kitap okuma alışkanlığı kazandırmak amacıyla yaptığı çalışmayı yeterli gördüğünü ifade ederken, 6'sı yaptığı çalışmaları yeterli görmediğini ifade etmiştir. Ayrıca öğrencilere okuma alışkanlığı kazandırmak amacıyla öğretmenlerin 6'sı okuma saati uygulaması yaptıklarını, 4 öğretmen hem ailelerini teşvik ettiklerini hem de öğrencilere okuma önerilerinde bulunduklarını, 3 öğretmenin ise öğrencilere okumanın öneminden bahsettiklerini, ödül verdiklerini, kendi istedikleri kitapları aldırdıklarını, öğrencileri kütüphaneye götürdüklerini, 2 öğretmenin ise öğrencilere kendinden örnekler verdiğini, öğrencileri kendi okudukları türe yönelttiklerini, 1'i de okuma yarışı ve başarılı insanlardan örnekler verdiğini belirtmiştir. Bu konuyla ilgili K1 kodlu öğretmen; "Şimdi şöyle bir durum var. Okuma saatlerinde düzenli kitap okumalarını sağlıyorum. Bazı öğrenciler dediğim gibi okumuyor. Özet çıkarttırıyorum. Yıldız yapıştırıyorum. Yeterli değil ama 4. Sınıfız çok fazla dersimiz var..." şeklinde ifade etmiştir.

Öğretmenlere, öğrencilerinin okumayı sevmelerinde etkili olan etmenlerin neler olduğu sorulmuş ve elde edilen veriler Tablo 2'de gösterilmiştir.

Tablo 2.

Öğretmenlerin Öğrencilerin Okumayı Sevmesindeki Etkenlere Yönelik Görüşleri

\begin{tabular}{lll}
\hline Öğrencilerin Okumayı Sevmesindeki Etkenler & Öğretmenler & Frekans \\
\hline Ödül & $\mathrm{K} 1, \mathrm{~K} 5$ & 2 \\
\hline
\end{tabular}




\begin{tabular}{lll}
\hline Nasihat & $\mathrm{K} 1, \mathrm{~K} 3, \mathrm{~K} 4, \mathrm{E} 7$ & 4 \\
Okuma Saati & $\mathrm{K} 1, \mathrm{~K} 2, \mathrm{~K} 3, \mathrm{~K} 4, \mathrm{~K} 5, \mathrm{E} 1, \mathrm{E} 2$ & 7 \\
Ailenin model olması & $\mathrm{K} 1, \mathrm{~K} 5, \mathrm{E} 1, \mathrm{~K} 8$ & 4 \\
Öğretmenle birlikte okuma & $\mathrm{K} 1, \mathrm{~K} 3, \mathrm{E} 1, \mathrm{E} 6$ & 4 \\
Kitapların resimli olması & $\mathrm{K} 2, \mathrm{~K} 4, \mathrm{~K} 6$ & 3 \\
Kitapla bütünleşme & $\mathrm{E} 2, \mathrm{~K} 8$ & 2 \\
Başarılı insanların örnek gösterilmesi & $\mathrm{K} 3$ & 1 \\
Kitap fuarı & $\mathrm{K} 4$ & 1 \\
Yeni kitaplar & $\mathrm{K} 4$ & 1 \\
Yeni bilgiler öğrenme merakı & $\mathrm{E} 2, \mathrm{E} 6, \mathrm{~K} 7, \mathrm{~K} 8, \mathrm{E} 3, \mathrm{E} 7$ & 6 \\
Boş zamanlarını değerlendirme amacı & $\mathrm{K} 6$ & 1 \\
\hline
\end{tabular}

Öğrencilerin okumayı sevmesinde rol oynayan etmenlere ilişkin olarak öğretmenlerin 7'si okuma saati uygulamasının etkili olduğunu ifade ederken, 6 'sı yeni bilgiler öğrenme merakının etkili olduğunu ifade etmiştir. Ayrıca öğretmenler; kitap fuarlarının, yeni kitapların, öğrencilerin boş zamanlarını değerlendirme amaçlarının da etkili olduğu yönünde görüş bildirmişlerdir. Etkili yöntemleri K1 kodlu öğretmen;

"... Mesela kitap okuma saati yapıyoruz. Belli öğrenciler çok güzel şekilde okurken, belli öğrenciler farklı farklı şeylerle ilgileniyor. Yani çocuğa bir dayatma yapmadan çocuk maalesef kitap okumuyor diye düşünüyorum. Ben ailenin de etkili olduğunu düşünüyorum. Şimdi ödüllendirme de diyeceğim tamam şimdi bazı öğrenciler de ödüllendirme yapıyorken, bu 6-7 öğrencide hiçbir etki etmemiş..." şeklinde ifade ederken, E6 kodlu öğretmen; "Okumayı sevmelerinde merak duyguları, şahsımında onlarla kitap okumasını söyleyebilirim." diyerek belirtmiştir.

Öğrencilerin kısa yoldan kitaplara erişim kaynağı olan sınıf kitaplıklarının olup olmadığı ve kitaplıkta olan kitapların nasıl elde edildiği öğretmenlere sorulmuş ve öğretmenlerin tamamı sınıflarında sınıf kitaplığı olduğunu ifade etmişlerdir ve bu öğretmenlerin 8'i sınıf kitaplıklarının kitaplarını kendilerinin satın aldığını, 6'sı geçen yıllardan kalan, 3'ü öğrenciler ve velilerin getirdikleri kitaplarla oluşturduklarını, 2'si öğrencilerle beraber aldıklarını, 1'i de kurumlardan, öğretmen arkadaşlarından ve üst sınıflardan kalan kitaplarla sınıf kitaplıklarını oluşturduklarını ifade etmiştir. Sınıf kitaplı̆ı̆ıdaki kitapları elde etmeyle ilgili K4 kodlu öğretmen;

"Var. Önceden kalan kitaplar 4. Sınıflardan kalan kitaplar, bazı velilerimiz destekliyor, çocuklar kendileri alıyorlar, getiriyorlar. Yıl sonunda o kitapları alıyorlar. Yani her yıl çocuklar bir kitap alıp şeye getiriyorlar kitaplığa. Ondan sonra onları yıl sonunda alıyorlar. Mesela bir kitabı hepsi okumuş oluyor."

şeklinde belirtirken, E3 kodlu öğretmen; "Sınıf kitaplığımız var. Kitaplığımızı oluştururken her öğrenci iki kitap kampanyası yaptık. Ayrıca çeşitli kurumlardan yardım talep ettik." diye ifade etmiştir.

Öğretmenlere okulda kütüphane olup olmadığı ve kütüphaneyi hangi sıklıkta kullandıkları sorulmuş; öğretmenlerin hepsi okul kütüphanesinin olduğunu ifade etmişlerdir. Bunun yanında öğretmenlerin 8'i okul kütüphanesini kullandığını ifade ederken, 7'si kütüphaneyi kullanmadığını ifade etmiştir. Kütüphaneye giden öğretmenlerden 3'ü ayda bir kütüphaneye gittiğini belirtirken, 2'si haftada bir kütüphaneye gittiğini, $1^{\prime} i$ ise sene başından beri 1 kez gittiğini ifade etmiştir. Kütüphane kullanma alışkanlığı ile ilgili K5 kodlu öğretmen;

"Var. Kullanıyoruz. Haftada 1 gün 1 saat iniyoruz kütüphaneye. Çünkü 4. Sınıf olduğumuz için konularımız ağırlaştı. Geçen sene olsaydı bu saati çok fazla artırıyorduk ama bu sene malum dersler, yazılılar, sınavlar dolayısıyla ayırıyoruz buna. Bazen 2 saate de çıkabiliyor bu."

şeklinde ifade ederken, E4 kodlu öğretmen; "iki bin beş yüz kitap olan kütüphanemiz var. Her dinlenme arası açıktır. Isteyen istediği kitapları alabilir." diyerek kütüphaneyi öğrencilerin kendilerinin kullanacağı mekanlar gibi yansıtmıştır.

Öğretmenlere, öğrencilerinin okumayı sevmeme nedenleri sorulmuş ve elde edilen veriler Tablo 3'te sunulmuştur. 
Tablo 3.

Öğretmenlere Göre Öğrencilerin Okumayı Sevmeme Nedenleri

\begin{tabular}{lll}
\hline Öğrencilerin Okumayı Sevmeme Nedenleri & Öğretmenler & Frekans \\
\hline Yanlış kitap seçimi & $\mathrm{K} 8$ & 1 \\
Öğrenciye ödül verilmemesi & $\mathrm{K} 1$ & 1 \\
Öğrencinin okuma güçlüğünün olması & $\mathrm{K} 1, \mathrm{~K} 6, \mathrm{E} 4, \mathrm{E} 5, \mathrm{~K} 7$ & 5 \\
Öğrencinin farklı ilgi alanlarına sahip olması. & $\mathrm{K} 4, \mathrm{~K} 7$ & 2 \\
Ailenin öğrenciye model olmaması & $\mathrm{K} 1, \mathrm{~K} 4, \mathrm{E} 1, \mathrm{E} 3, \mathrm{E} 4, \mathrm{~K} 8, \mathrm{~K} 9$ & 7 \\
Öğrencinin hareketli olması ve dikkat eksikliğinin olması & $\mathrm{K} 2, \mathrm{~K} 3, \mathrm{E} 5, \mathrm{~K} 7$ & 4 \\
Okumayla ilgili olumsuz yaşantıya sahip olması & $\mathrm{K} 5$ & 1 \\
Öğrencinin okumayı gereksiz bulması & $\mathrm{K} 3$ & 1 \\
Kitapları sıkıcı bulması & $\mathrm{K} 6$ & 1 \\
Öğrencinin yeterli kitabı olmaması & $\mathrm{K} 7, \mathrm{~K} 8$ & 2 \\
\hline
\end{tabular}

Öğretmenlerin çoğu, öğrencilerinin okumayı sevmemelerine neden olarak ailelerinin model olmamalarını göstermişlerdir. Buna ilaveten öğretmenler, öğrencilerin okuma güçlüğü yaşamalarını, hareketli olmalarını ve dikkat eksikliği yaşamalarını da okumayı sevmemelerinde rol oynayan nedenler arasında göstermişlerdir. Konuyla alakalı K4 kodlu öğretmen; "4-5 tanesinin hiç alakası yok. Ne olabilir? Belki aile desteklemiyor. Bunların birçoğu 4-5 tanesinin aile düzeni çok iyi değil. Evde kitap okunmuyordur, kitap okuyanı görmüyordur çocuk..." diye ifade etmiştir.

\section{Velilerin çocuklarının okuma alışkanlıklarına iliş̧in görüşleri}

Araştırmanın bu bölümünde öğrenci velilerinin, çocuklarının okumayı sevmelerine etki eden etmenler, evlerinde kitaplık bulunup bulunmadığı ve kitaplıktaki kitapları nasıl temin ettikleri, bulundukları yerlerde halk kütüphanesinin olup olmadığı ve buradaki kütüphaneleri hangi sıklıkta ziyaret ettikleri hakkındaki görüşleri ile ilgili bilgiler verilmiştir.

Velilere, çocuklarının okumayı sevmelerine etki eden etmenler sorulmuş ve velilerin görüşleri Tablo 4'te gösterilmiştir.

Tablo 4.

Velilerin, Öğrencilerin Okumayı Sevmesindeki Etkenlere Yönelik Görüşleri

\begin{tabular}{|c|c|c|c|}
\hline $\begin{array}{l}\text { Çocuğunuz } \\
\text { Okumayı Seviyor } \\
\text { mu? }\end{array}$ & $\begin{array}{l}\text { Öğrencilerin Okumayı Sevip-Sevmesindeki } \\
\text { Etkenler }\end{array}$ & Veliler & Frekans \\
\hline \multirow{9}{*}{ Evet } & Aile desteği & V2, V8,V11 & 3 \\
\hline & Öğretmen desteği & V2, V3 & 2 \\
\hline & Okumaya istekli oluşu, sevmesi & V3, V5 & 2 \\
\hline & Merak & V4, & 1 \\
\hline & İlgi çekici kitaplar & V4 & 1 \\
\hline & Büyüklerini örnek alması & V5 & 1 \\
\hline & Kendisini geliştirme çabası & V5, V6, V7, V9, & 4 \\
\hline & Aileyi model alması & $\mathrm{V} 8, \mathrm{~V} 13, \mathrm{~V} 14$ & 3 \\
\hline & Vakit geçirme amacı & v9 & 1 \\
\hline \multirow{3}{*}{ Hayır } & Gözlerinin yorulması & V1 & 1 \\
\hline & TV izlemesi & V12, & 1 \\
\hline & Küçük kardeşine özenmesi & V10, & 1 \\
\hline
\end{tabular}

Tablo 4'te veliler, öğrencilerin okumayı sevmelerinde etkili olan yollara ilişkin olarak; öğrencilerinin en çok kendilerini geliştirme amacıyla okuduklarını ifade etmişlerdir. Ayrıca veliler; ailelerin, çocuklarına destek olmalarııı yanında çocuklarına model olmaları sayesinde okuma sevgilerinin oluştuğunu ifade etmişlerdir. Konuyla alakalı V9 kodlu veli; "Çok küçük yaştan itibaren, ögrrenme isteği vardı." şeklinde belirtirken, V8 kodlu veli; "En önemli etken ebeveynlerin kitap okuması, küçüklüğünden itibaren çocuğuna kitaplar okuması, kitaba verdiği değeri zaman zaman vurgulaması etkendir." şeklinde ifade etmiştir. 
Velilere evlerinde kitaplık olup olmadığı ve kitaplıktaki kitapları nasıl temin ettikleri sorulmuş; velilerden 13'ü evlerinde kitaplıklarının olduğunu, 2'si olmadığını ifade etmişlerdir. Veliler "Evlerindeki kitaplığı nasıl oluşturdunuz?" sorusu hakkında toplam 18 görüş belirtmiştir. Bu görüşlerin 10'u kendilerinin aldığı; $5^{\prime} i$ hediye gelen kitaplar ile, $1^{\prime} i$ de kupon biriktirme, halk kütüphanesinden ve okuldan verilen kitaplar sayesinde oluşturduklarını ifade etmiştir. Bu konuyla alakalı V3 kodlu veli, "Çocuğumun kitaplığı var. Kitapları biz temin ettik." diye ifade ederken, V5 kodlu veli; "Var. Kitap kuponları biriktirerek, para ile satın alarak." V9 kodlu veli de; "Kitaplık var. Kitapları kırtasiyeden aldık." diye ifade etmiştir.

Velilere yaşadıkları yerde kütüphane olup olmadığı ve kütüphaneye hangi sıklıkta uğradıkları sorulmuş ve velilerin 10'unun oturduğu bölgede halk kütüphanesi olmadığını, 5'inin oturduğu bölgede halk kütüphanesi olduğunu belirtmiştir. Ayrıca velilerin $11^{\prime}$ inin kütüphaneye gitmediği, 4'ünün gittiği; giden 4 velinin ise her birinin bazen, haftada 1, her zaman, sık sık gittiği ortaya çıkmıştır. Konuyla ilgili V14; "Okul kütüphanesinin dışında yok" şeklinde ifade ederken, V7 kodlu veli; "Evet. Çocuğumun ve benim kütüphane kartımız var. Geçen sene haftada bir gidiyorduk. Tadilat nedeniyle kapatıldı." diyerek görüşlerini ifade etmiştir.

\section{Tartışma, Sonuç ve Öneriler}

Araştırmada öğrencilerin ders kitabı dışında her gün düzenli kitap okudukları sonucu ortaya çıkmıştır. Öğrencilerin ders kitabı dışında her gün düzenli okumalarının altında; okumadan hoşlanmaları, boş zamanlarını değerlendirme ve eğlenme çabaları; anne-babalarının, öğretmenlerinin beğenisini toplama gayretleri ve eğitim başarılarını artırma amaçları gibi nedenler yatıyor olabilir. Hatta bu konuda öğrenci velilerine, "Çocuğunuz okumayı seviyor mu? Seviyorsa sevmelerinde nelerin etkili olduğu, sevmiyorsa nelerin neden olduğunu düşünüyorsunuz?" sorusu sorulmuş ve veliler, çocuklarının kendilerini geliştirmek için okuduklarını ifade etmişlerdir. İşcan, Arıkan ve Küçükaydın'ın (2013) ilköğretim öğrencilerine yönelik yaptığı çalışmada da öğrencilerin düzenli olarak kitap okudukları sonucuna ulaşılmıştır. Hatta Aksoy'un (2014) velilere yönelik yaptığı araştırmada da velilerin, öğrencilerinin düzenli olarak okuduğunu ifade ettikleri görülmüştür. Fakat Demirer ve diğerleri (2010) tarafından yapılan çalışmada; öğrencilerin yarısından fazlasının haftada 2-3 gün kitap okuduğu; Şahin'in (2012) tarafından yapılan çalışmada ise orta sosyo-ekonomik düzeydeki öğrencilerin haftada birden çok kitap okumayı tercih ettiği, alt sosyoekonomik düzeydeki öğrencilerin haftada bir kitap okumayı tercih ettiği görülmüştür. Öğrencilerin ders kitapları dışında düzenli kitap okumalarında farklılıklar yaşamalarının altında; bilgi ve birikimlerini artırma, kendilerini daha iyi ifade etme gibi zihinsel becerilerini geliştirme durumları yatıyor olabilir.

Öğrencilerin ders kitabı dışında 10 ve daha az sayıda kitaplarının olduğu sonucuna ulaşılmıştır. Gönen, Öncü ve Işıtan (2004) tarafından yapılan bir araştırmada, üst sosyo-ekonomik düzeydeki ailelerin çocuklarına daha fazla kitap aldıkları ortaya çıkmıştır. Bu araştırmadaki öğrencilerin ailelerinin düşük ekonomik gelirli olmaları, çocuklarına ayıracakları bütçeyi sınırlıyor ve bu da ailelerin çocuklarına kitap almalarını engelliyor olabilir. Geçgel ve Burgul'un (2009) yaptıkları çalışmada ise, eğitim fakültesi öğrencilerinin kitaplıklarında 11-20 arasında kitap bulunduğu tespit edilmiştir. Bu bağlamda gerek üniversite öğrencilerinin gerekse ilkokul öğrencilerinin düşük ekonomik gelirli olmaları yeterli sayıda kitaba sahip olmalarının önündeki engel olarak düşünülebilir.

Öğrencilerin ders kitabı dışında bir yılda 6-10 kitap okuduğu görülmüştür. Arıcı (2005) da ilköğretim öğrencilerinin yılda 7-10 kitap okuduğu sonucuna ulaşmıştır. Yılmaz (1990) ise; yılda 21 ve daha fazla kitap okuyanın üst düzey okuyucu, 6-20 kitap okuyanın orta düzey okuyucu, 1-5 kitap okuyanın az okuyucu, okuyucu olmayanın ise hiç kitap okumadığını belirtmektedir. Araştırmadaki öğrenciler, düzenli olarak kitap okuduklarını ifade etmelerine rağmen öğrencilerin bir yılda okudukları kitap sayılarına bakıldığında orta düzeyde okuyucular olduğu görülmektedir. Bu öğrencilerin, kendilerini düzenli okuyucu olarak görmelerinin sebebi, her gün kitap okumaları olabilir. Ancak her gün kitap okuyan bu çocukların, iyi bir okuyucu olmaları için bir yılda okumaları gereken kitap sayısının önündeki engel, zamanlarının çoğunu okulda geçirmeleri olabilir. Yapılan birçok araştırmada da öğrencilerin orta ve üst düzey ve etkin okuyucu, okuma ilgisine sahip oldukları, okumaktan zevk aldıkları görülmüştür (Aksaçlıoğlu ve Yılmaz, 2007; Aksoy, 2014; Balcı, Uyar ve Büyükikiz, 2012; Gönen, 
Öncü ve Işıtan, 2004; İşcan, Arıkan, Küçükaydın, 2012; Kurulgan ve Çekerol, 2008; Oyelude, 2013; Saracaloğlu ve Aslantürk, 2010; Suna, 2006; Yılmaz, 2012). Bunların aksine birçok araştırmada da öğrencilerin çoğunun hiç kitap okumadığı, yetersiz, zayıf okuma alışkanlığına, düşük ve odaksız okuma becerisine sahip, okumaktan zevk almayan, okumayı önemli görseler de okumaya yeterli zamanı ayırmadıkları sonuçlarına ulaşılmışır (Al-Musalli, 2014; Ateş ve Şahin, 2014; Elkatmış, 2013; Gür, 2014; Korkmaz, 2007; Pehlivan, Serin ve Serin, 2010; Rimensberger, 2014; Yalman, Özkan ve Kutluca, 2013; Yılmaz, 2006). Bu bağlamda öğrencilerin okuma düzeyleri arasında farklılıklar yaşandığı, bu farklılıkların ise okumaya ayrılan zaman, okuma ilgi ve ihtiyaçları, okumaya engel durumlar (bilgisayar, televizyon, ev işleri, kitap sayısının yetersizliği vb.) gibi nedenlerden kaynaklandığı söylenebilir.

Araştırmada öğrencilerin anne ve babalarının ara sıra okuduğu sonucuna ulaşılmıştır. Okuma kültürü oluşan ailelerin ise eğitim ve gelir düzeylerinin yüksek olduğu görülmektedir (Odabaş, Odabaş ve Polat, 2008; Sağlam, Suna ve Çengelci, 2008; Smaragdi ve Jönsson, 2006). Araştırmadaki öğrencilerin çoğunun babasının iş̧̧i olarak çalışması, onların okumaya yeteri kadar vakit ayıramamalarının nedeni olabilir. Babaların, zamanlarının büyük çoğunluğunu çalıştıkları yerde geçirmeleri nedeni ile ev işleri çalışmayan annelere kalıyor olabilir. Zamanını ev işleri ile geçiren anneler de kitap okumaya yeteri kadar zaman bulamıyor olabilir.

Araştırmada ilkokul 4. sınıf öğrencilerinin en çok hikaye kitabı okudukları görülmüştür. Yapılan bazı araştırmalarda da öğrencilerin en fazla öyküyü tercih ettiği görülmüştür (Acat, Demiral ve Arın, 2008; Aksoy, 2014; Yaman ve Süğümlü, 2010). Bunun nedeni ise, Piaget'in bilişsel gelişim dönemine göre somut işlemler döneminde olan öğrencilerin, kolayca hayal edebilecekleri gerçek durumlarla bağlantılı somut düşünce deneyleri gerçekleştirmeleridir (Akbaba ve diğerleri, 2009). Öğrenciler de bu fırsatı hikayeler sayesinde yakalıyor olabilir. Ayrıca ilköğretim 4. sınıfta okuyan bu çocukların gelişimleri gereği dış dünyaya karşı ilgilerinin artması bu türe ilgi duymalarının bir başka sebebidir (Şahin ve diğerleri, 2011).

Birçok araştırmada olduğu gibi bu araştırmada da öğrencilerin macera konulu kitapları tercih ettikleri sonucuna ulaşılmıştır (Aksoy, 2014; Bayis, 2010; İşcan, Arıkan ve Küçükaydın, 2013). Macera konulu kitapların gerçek konuları taşıyor olması, bu kitapların öğrenciler tarafından daha fazla tercih edilmesinin sebebi olabilir. Çünkü bu dönem çocuklarının ilgileri, düş ürünü konulardan gerçek konulara doğru arttığı için macera konulu kitaplarla daha çok ilgilenirler (Kıbrıs, 2010). Macera konulu bu kitapların sürükleyici olay dizisine sahip olması, çocukların heyecan duygularını uyandırarak, onların kitaplara olan meraklarını artırıyor olabilir.

Araştırmada öğrencilerin öykü kitabı dışında en çok dergiyi tercih ettikleri görülmüştür. İşcan, Arıkan ve Küçükaydın, (2013) da aynı sonucuna ulaşmıştır. Öğrencilerin velileri bu durumun; dergilerin, dikkat çekici ve renkli olmasından dolayı çocuklarının eğlenceli vakit geçirmelerine yardımcı olduğunu belirtmişlerdir (Topçuoğlu, Ünal ve Yiğit, 2014). Dergilerin, çocukların güncel olaylarla ilgilenmelerini ve günlük okumalarını sağlayan en etkili araç-gereçler olması (Kıbrıs, 2010), öğrencilerin okuma zevk ve alışkanlığını geliştirmelerine yardımcı olmaktadır (Balcı, 2003; Şahin ve diğerleri, 2011).

Araştırmada öğrencilerin kitap seçerken en çok konusuna dikkat ettikleri ortaya çıkmıştır. Kitap konularının öğrencilerin yaşantılarından örnekler taşıması (Demircan, 2006), bu kitapların tercih edilme nedeni olabilir. Öğrencilerin yanında, öğretmen, öğretmen adayları ve okul yöneticilerinin de kitap seçerken öncelikle kitapların konusuna dikkat ettikleri görülmüştür (Arıcı, 2005; Geçgel ve Burgul, 2009; Konan, 2013; Konan ve Oğuz, 2009; Yağcl, 2007). Hangi yaş grubu olursa olsun insanların kitaplarda yaşamlarından izler aradığı, bu izleri de kitapların konularına bakarak buldukları düşünülebilir

Araştırmada öğrencilerin okudukları kitapları daha çok anne ya da babalarıyla aldıkları sonucuna ulaşıımıştır. İşcan, Arıkan ve Küçükaydın (2013) tarafından yapılan bir araştırmada ise, öğrencilerin okuyacakları kitapları okul kitaplığı ya da kütüphaneden temin ettikleri sonucuna ulaşıımıştır. Bunun yanında birçok araştırmada öğrencilerin okuyacakları kitapları, satın alma yoluyla ya da arkadaşlarından ödünç alarak elde ettikleri sonucuna ulaşılımışıı (Kurulgan ve Çekerol, 2008; Pehlivan, Serin, Serin, 2010; Saracaloğlu, Karasakaloğlu ve Aslantürk, 2010; Yalman, Özkan ve Kutluca, 2013; Yılmaz, Köse, Korkut, 2009). Bu bağlamda kitapların farklı yollardan temin edildikleri, bunun 
nedeni ise ailelerinin ekonomik düzeylerinden ve öğrencilerin kitaplara ulaşılabilme durumlarından kaynaklanıyor olabilir.

Öğrencilerin kütüphaneyi roman ve hikaye almak için kullandıkları ortaya çıkmıştır. Bu da öğrencilerin kütüphaneden nasıl yararlanacaklarını bilmemelerinden kaynaklanıyor olabilir (Dökmen, 1990). Çünkü kütüphaneler, öğrencileri kitaba ulaştırmasının yanında; ders çalışma, araştırma yapma, ödev yapma, sınavlara hazırlanma, kitap ve ansiklopedilere bakma ve proje ödevlerini hazırlama gibi olanaklar sağlamaktadır (Abeyrathna ve Zainab, 2004; Arıcı, 2005; Bayis, 2010; Dökmen, 1990; Erdamar ve Demirel, 2009; Gönen, Öncü ve Işıtan, 2004; İşcan, Arıkan ve Küçükaydın, 2013; Kurulgan ve Çekerol, 2008; Sevmez, 2009; Yılmaz, Köse ve Korkut, 2009). Araştırmadaki öğrencilerin ne anne-babalarıyla ne de öğretmenleriyle yeterince kütüphaneye gitmedikleri görülmüştür. Öğretmenlerin öğrencileriyle kütüphaneye yeteri kadar gidememelerinin altında; ders müfredatlarının yoğun olması ve müfredat konularını yetiştirme çabaları gibi nedenler yatıyor olabilir. Ailelerin ise yaşadıkları yerde kütüphane olmayabilir.

Öğrencilerin kitap okumalarına ev işleri, kitap fiyatlarının pahalı olması, ödevlerin çokluğu, evde çalışma ortamının olmaması ve arkadaşlarıyla görüşmeleri engel olmamasına rağmen, televizyonun engel olduğu ortaya çıkmıştır. Televizyonun her evde bulunması, kolay ulaşılabilir bir araç olması, göze ve kulağa hitap etmesi çocukları etkileyebilmektedir (Aral ve Aktaş, 1997). İşcan, Arıkan ve Küçükaydın (2013) ile Demirer, Yıldız ve Sünbül (2011) tarafından yürütülen araştırmalarda da televizyonun okumaya engel olduğu sonucuna ulaşılırken, yapılan başka araştırmalarda televizyonun yanında bilgisayar ve internetin okumaya engel olduğu sonucu ortaya çıkmıştır (Aksaçlıoğlu ve Yılmaz, 2007; Huang, Capps, Blacklock, ve Garza, 2014; Mokhtari, Reichard ve Gardner, 2009; Özer ve Doğan, 2013; Sevmez, 2009; Yaman ve Süğümlü, 2010; Topçuoğlu ve Yiğit, 2014; Yılmaz, Köse ve Korkut, 2009). Yapılan farklı araştırmalarda ise; arkadaş ortamı, zaman yetersizliği, yorgunluk, okuma alışkanlığının yetersizliği ve kitap/dergilerin pahalılı̆ı gibi nedenlerin öğrencilerin okumalarına engel olduğu görülmüştür (Bayis, 2010; Geçgel ve Burgul, 2009; Karaşahin, 2009; Konan ve Oğuz, 2009; Kuş ve Türkyılmaz, 2010; Odabaş, Odabaş ve Polat, 2008; Saracaloğlu, Karasakaloğlu ve Aslantürk, 2010; Saracaloğlu vd., 2009; Yalman, Özkan ve Kutluca, 2013; Yılmaz, 2002). Tüm bu bulgulardan hareketle bireysel ve çevresel etkenlerin okuma alışkanlığııın kazanılmasını engellediği düşünülebilir.

Okuma alışkanlığı eğitimde verimliliği ve başarıyı artıran unsurlardan biridir (Yılmaz, 2012). Okuma alışkanlığının geliştirilmesinde; öğretmenler, aileler ve öğrencilerin arkadaşları etkilidir (Bayis, 2010). Aşılıoğlu (2008) tarafından yapılan araştırmada öğrenci velileri, çocuklarının okuma alışkanlığını ancak okulda kazanabileceklerini düşünmektedirler. Okulda, öğrencilerin okuma alışkanlığının gelişmesine öğretmenler önemli rol oynamaktadır (Arıı,2005). Araştırmadaki öğretmenler, okulda okuma saati uygulaması yaparak bu görevi yerine getirdiklerini ifade etmişlerdir. Aksoy'un (2014) yaptığı araştırmada ise; öğretmenlerin, öğrencilere okuma alışkanlığı kazandırmak için velilerle işbirliği yaptıkları ve ödül verdikleri ortaya çıkmıştır. Evde öğrencilerinin okumaya yeteri kadar zaman ayırmadıklarını düşünen öğretmenler, bu eksikliği okulda okumaya özel olarak zaman ayırarak telafi ediyor olabilir. Hatta araştırmadaki öğretmenler okuma saati uygulamasını, öğrencilerinin kitap okumayı sevmelerindeki etkili yol olarak ifade etmektedirler. Okumaya özel olarak ayrılan bu sürede tek amaç kitap okumaktır. Bu sürede kitap okumaktan başka faaliyet yapılmıyor olması, öğrencilerin okumaya karşı ilgilerini artırıyor olabilir.

Çocukların okumayı modelden öğrenebilecekleri ilk ve en önemli ortam aileler olduğu gibi kitap okuma sevgisi aşılamada kişinin kendisinin yanında anne babası da önemlidir. Fakat bu araştırmada öğretmenler; öğrencilerin okumayı sevmemesinde, ailelerinin model olamamasını göstermişlerdir. Bu durumun kanıtı olarak ise araştırmadaki ailelerin ara sıra kitap okudukları sonucu gösterilebilir. Çünkü çocuğu tarafından sürekli kitap okurken görülmeyen ailelerin, çocuklarının kitap okumaya ilgisini çekmede yetersiz kalacağı düşünülebilir. Halbuki evde sürekli okuyan bir anne babanın ya da kardeşlerin olması; ailelerin kitap okumayı sevmesi ya da kitapla ilgili konuşması, çocukları etkileyebileceği gibi çocukların okumaya olan ilgilerini artırabilir (Batur, Gülveren ve Bek, 2010; Ronkova ve Wildova, 2015). Literatüre bakıldığında birçok araştırmada, ailelerin okumayı seven kişiler olduğu, çocuklarına kitap aldığı, model olduğu ve yol gösterdiği görülmüştür (Arıcı, 2009; Gönen, Öncü ve Işıtan, 2004; Topçuoğlu ve Yiğit, 2014). Bu bağlamda, öğrencilerin okuma alışkanlığını kazanmasında 
özel ve devlet kurumları, kitle iletişim araçları, kütüphane gibi etkenlerin yanında ailenin desteği gerekmektedir (Sangkeo, 1999).

Okumayı gerçekleştirmek için kaynağa ulaşmada en büyük yardımcı öncelikle sınıf kitaplıklarıdır (Şahin, İşcan ve Maden, 2009). Bu araştırmada öğretmenler, sınıflarında sınıf kitaplıklarının olduğunu ifade etmiştir. Literatüre bakıldığında da öğrencilerin sınıflarında kitaplıklarının olduğu, öğrencilerin de buralardan faydalandığı görülmektedir (Balcı, Uyar ve Büyükikiz, 2012; Bayis, 2010). Ayrıca araştırmadaki öğretmenler bu kitaplıklardaki kitapları, kendilerinin aldığını belirtmiştir. Aksoy'un (2014) yaptığı bir araştırmada ise, öğretmenlerin sınıf kitaplıklarını öğrencileriyle birlikte oluşturduğu sonucuna ulaşıımıştır. Öğretmenlerin kitapları kendilerinin almalarının altında; öğrencilerini iyi tanımaları, ilgi ve ihtiyaçlarını bilmeleri, onların zevklerine ve seviyelerine uygun kitapları kendilerinin seçebilecekleri inancı gibi nedenler yatıyor olabilir.

Aksoy'un (2014) araştırmasında olduğu gibi araştırmadaki öğretmenlerin okullarında bulunan kütüphaneyi sıklıkla kullanmadıkları ortaya çıkmıştır. Öğretmenler; ders müfredatlarının yoğun olması, kazanımlar için yeterli sürenin olmaması gibi nedenlerden dolayı derslerdeki kazanımları yetiştirme gayreti içinde olabilirler. Bu süreç içinde ayrıca kütüphaneye gitmenin kendilerine zaman kaybettireceğini düşünüyor olabilirler. Öğretmenlerin kütüphaneye gidip gelmede süre harcamak yerine, müfredatı yetiştirmeye odaklanmaları, kütüphaneyi sık kullanmalarına engel oluyor olabilir. Öğretmenleriyle kütüphaneye yeteri kadar gitmeyen öğrenciler, ne kütüphanede nasıl davranacaklarını bilebilirler ne de kütüphanenin hangi amaçlara hizmet ettiğini bilebilirler. Meslek yüksekokulu öğrencilerine yönelik yapılan araştırmada öğrencilerin yarısından fazlasının kütüphane kullanımı hakkında bilgi sahibi olmalarına rağmen, sınıf öğretmeni adaylarının üçte ikisinin kütüphaneyi kullanmayı kendi kendine öğrendikleri görülmüştür (Kurulgan ve Çekerol, 2008; Saracaloğlu, Karasakaloğlu ve Aslantürk, 2010). Dökmen'in (1990) yaptığı bir araştırmada ise, lise ve üniversite öğrencilerinden kütüphaneyi nasıl kullanacaklarını bilmedikleri ortaya çıkmıştır. Öğretmenlerin ilkokul yıllarında öğrencileri ile okul kütüphanelerini yeteri kadar kullanmamaları, ilerleyen eğitim düzeyindeki öğrencilerin gerek kütüphane bilincinin gerekse okuma kültürünün oluşmasının önündeki engel olabilir.

Veliler çocuklarının okumayı sevdiğini, okumayı sevmelerinde ise çocuklarının kendilerini geliştirme amacının yattığını düşünmektedirler. Okuma, bireyin gerek okul yaşamı boyunca gerekse okul yaşamı bittikten sonra kendi kendini eğitmesini, olayları doğru ve anlamlı biçimde analiz edip, sentezleyip, yorumlamasını sağlayan bir beceridir. Velilerin de okumanın bu öneminin farkında olmaları böyle düşünmelerinin nedeni olabilir. Arıcı'nın (2009) üniversite öğrencilerinin okumayı nasıl sevdikleri üzerine yaptığı çalışmada, mülakata katılan gençlerin, ailelerinin özellikle anne ve babalarının okuma konusunda kendilerine yol gösterdiklerini, onların da genelde okumayı seven kişiler oldukları için onları model aldıklarından bahsetmektedir. Ailenin yanında öğretmen ve arkadaş çevresi de öğrencilerin okumayı sevmelerinde etkilidir (Sevmez, 2009). Bu sonuçlardan da okumayı sevme konusunda içsel ve dışsal faktörlerin önemli bir rolünün olduğu düşünülebilir.

Araştırmaya katılan veliler, evlerinde kitaplıklarının olduğunu ifade etmişlerdir. Kitap okumanın bir eğitim etkinliği olarak işlevini sürdürebilmesi için evlerde ve okullarda zengin bir kitaplık oluşturmaya özen gösterilmesi gerekmektedir (Durualp, Çiçekoğlu ve Durualp, 2013). Araştırmadaki veliler de bu durumun farkında olduklarından evlerinde bu yüzden kitaplık kurmuş olabilirler. Literatüre bakıldığında da, öğrencilerin evlerinde kitaplık olduğu görülmüştür (Konan, 2013; Konan ve Oğuz, 2009). Ayrıca evlerinde kitaplık olan çocukların ailelerinin eğitim seviyesinin, ailelerin sosyo-ekonomik düzeylerinin yüksek olduğu ve bu ailelerin evlerine daha fazla kitap aldıkları görülmüştür (Gönen, Öncü ve Işıtan, 2004; Oyelude, 2013). Araştırmadaki veliler, evlerinde olan kitaplıklara kendilerinin kitap aldıklarını ifade etmişlerdir. Aksoy (2014) da aynı sonuca ulaşırken; Arıcı (2005) öğrencilerin anne babalarıyla gidip kitapları çocukların seçtiği sonucuna ulaşmıştır. Araştırmalarda farklı sonuçlar çıkmasının nedeni ailelerin eğitim düzeyleri olabilir. Çünkü araştırmada eğitim düzeyi düşük olan aileler kitapları kendileri alırken, farklı araştırmalar göstermektedir ki eğitim düzeyi yüksek olan ailelerin çocuklarıyla birlikte kitap almaya gittiklerini göstermektedir. Bu da onların çocuk eğitimi konusunda daha fazla bilgiye sahip olduğunun göstergesi olabilir. Bu nedenle de tercihleri çocuklarına bıraktıkları düşünülebilir. 
Araştırmada veliler, oturdukları yerde kütüphane olmadığını, çocuklarıyla kütüphaneye gitmediklerini ifade etmişlerdir. Bulundukları yerde kütüphane bulunmayan düşük sosyoekonomik düzeyli aileler, uzaktaki kütüphaneye gitmek için yapacakları harcamayı, çocuklarına kitap alarak kullanmayı, bu sayede de kitaplıklarını zenginleştirmeyi düşünüyor olabilirler. Oysa kütüphane, hem öğrencilerin hem de öğretmenlerin okuma alışkanlığı kazanmalarını artıracak ortamlardandır (Oyelude, 2013). Gönen, Öncü ve Işıtan'ın (2004) yaptıkları araştırmada da, çocuk ve halk kütüphanelerinin yetersiz olduğu sonucuna ulaşırken, Aksoy, (2014) öğrencilerin, velileriyle birlikte kütüphaneye gitmedikleri sonucuna ulaşmıştır (Aksoy, 2014). Tüm bu sonuçlara bakılarak ailelerin çocuklarıyla birlikte kütüphane kullanma konusunda yeterli bilince sahip olmadıkları düşünülebilir.

\section{Öneriler}

- Öğrencilerin orta düzeydeki okuma alışkanlıklarını üst düzeye çıkarabilmek için; öğretmenler, öğrencilerinin okumaya karşı ilgi ve meraklarını geliştirme çalışmaları yapabilirler.

- Düşük gelirli ailelerin çocuklarının kitap eksikliğini karşılayabilmek için yüksek gelirli ailelerden kitap yardımı isteğinde bulunulabilir.

- Çocuklara doğru modeller olabilmek için okullarda ailelerle birlikte okuma saatleri düzenlenebilir.

- Öğrencilerin kitaplara olan ilgilerini artırabilmek için kendi ihtiyaçlarına uygun kitaplar seçmelerine fırsatlar ya da kitap alırken onların fikirlerini değer verilebilir.

- Öğrencilerin, kütüphanenin sadece ödünç kitap almak amacıyla kullanılan bir yer olmadığını anlamaları için, sık sık kütüphane ziyaretleri yapılabilir.

- Öğrencilerin okumalarına engel olan televizyonun, hayatlarındaki etkisini azaltabilmek için, aileler, akşam saatlerinde çocuklarıyla birlikte kitap okuma, çocuklarına okudukları kitabı anlattırma, hikaye canlandırma faaliyetleri yapılabilir.

- Araştırma yapılan bu yaş grubundaki öğrencilerin, okuma alışanlığı düzeylerini belirlemek için boylamsal çalışmalar yapılabilir.

- Öğrencilerin kitap okuma alışkanlığının ne zaman başladığını belirlemeye yönelik gözleme dayalı çalışmalar yapılabilir.

\section{Kaynaklar}

Abeyrathna, P. H. A. S. and Zainab, A. N. (2004). The Status of reading habit and intersts among secondary school children in Srı Lanka. Malaysian Journal of Library \& Information Science, 9(2), 109-123.

Acat, B., Demiral, H. ve Arın, A. (2008). Okuma alışkanlığı göstergelerine göre ilköğretim öğrencilerinin durumları. https://www.academia.edu/ adresinden 05.06.2016 tarihinde edinilmiştir.

Akbaba, S., Ceyhan, A. A., Ceyhan, E., Cihangir-Çankaya, T., Güven, M., Hamamcı, Z., Kalkan, M., Küçükahmet, L., Şahin, H., Şahin, M., Palancı, M. ve Yazıcı, H. (Ed.). (2009). Eğitim psikolojisi. Ankara: Pegem Akademi.

Aksaçlıoğlu, A. G. ve Yılmaz, B. (2007). Öğrencilerin televizyon izlemeleri ve bilgisayar kullanmalarının okuma alışkanlıkları üzerine etkisi. Türk Kütüphaneciliği, 21(1), 3-28.

Aksaçlıoğlu, A. G. (2005). Öğrencilerin televizyon izleme ve bilgisayar kullanmalarının okuma alışkanlıkları üzerine etkisi. Yayınlanmamış yüksek lisans tezi, Hacettepe Üniversitesi Sosyal Bilimler Enstitüsü, Bilgi ve Belge Yönetim Anabilim Dalı, Ankara.

Aksoy, E. (2014). Illköğretim öğrencilerinin okuma alışkanlığına ilişkin veli, öğretmen ve öğrenci görüşleri. Yayınlanmamış yüksek lisans tezi, Abant İzzet Baysal Üniversitesi Eğitim Bilimleri Enstitüsü, Bolu.

Akyol, H. (2013). Türkçe ilk okuma yazma öğretimi. Ankara: PegemA Akademi.

Al-Musalli, A. (2014). Redefining the reading culture: Overcoming EFL teachers' prejudices against students'reading habits. Arab World English Journal, 5(1), 211-223. 
Arıcı, A. F. (2005). İlköğretim ikinci kademe öğrencilerinin okuma durumları (Beceri-ilgi-AlışkanlıkEğilim). Yayınlanmamış doktora tezi, Atatürk Üniversitesi Sosyal Bilimler Enstitüsü, Türkçe Eğitimi Ana Bilim Dalı, Erzurum.

Aslantürk, E. ve Saracaloğlu, A. S. (2010). Sınıf öğretmenleri ve sınıf öğretmeni adaylarının okuma ilgi ve alışkanlıklarının karşılaştııılması. Anadolu Üniversitesi Sosyal Bilimler Dergisi, 11(1), 155-176.

Aşılıoğlu, B. (2008). Bilişsel öğrenmeler için eleştirel okumanın önemi ve onu geliştirme yolları. Dicle Üniversitesi Ziya Gökalp Eğitim Fakültesi Dergisi, 10, 1-11.

Ateş, V. ve Şahin, S. (2014). Yüksek lisans öğrencilerinin okuma alışkanlıklarına bilgisayar ve internet teknolojilerinin etkileri. Ahi Evran Üniversitesi Kırşehir Eğitim Fakültesi Dergisi (KEFAD), 15(2), 1-16.

Aydın Yılmaz, Z. (2006). The Reading habit of elementary school teacher candidates. Illköğretim Online, $5(1), 1-6$.

Balcı, A. (2013). Bir okuma materyali olarak çocuk dergileri ve "Çocuklara Rehber". TUBAR, 13, 319349.

Balcı, A., Uyar, Y. ve Büyükikiz, K. K. (2012). İlköğretim 6. sınıf öğrencilerinin okuma alışkanlıkları, kütüphane kullanma sıklıkları ve okumaya yönelik tutumlarının incelenmesi. Turkish Studies, 7(4), 965-985.

Batur, Z., Gülveren H. ve Bek H. (2010). Öğretmen adaylarının okuma alışkanlıkları üzerine bir araştırma: Uşak Eğitim Fakültesi Örneği. Uşak Üniversitesi Sosyal Bilimler Dergisi, 3(1), 32-49.

Bayis, S. (2010). 4., 5., 6., 7. sınıf öğrencilerinin kitap okuma ve kütüphane kullanım alışkanlıklarının incelenmesi. Yayınlanmamış yüksek lisans tezi, Hacettepe Üniversitesi Sağlık Bilimleri Enstitüsü, Ankara.

Can, R., Türkyılmaz, M. ve Karadeniz, A. (2010). Ergenlik dönemi öğrencilerinin okuma alışkanlıkları. Ahi Evran Üniversitesi Eğitim Fakültesi Dergisi, Cilt 11, Sayı 3, Sayfa 1-21.

Demirer, V., Sünbül, A. M., Yılmaz, E., Ceran, D., Işık, A., Çintaş, D., Çalışkan, M. ve Alan, S. (2010). Illköğretim öğrencileri kitap okuma alışkanlıkları: Konya ili araştırma raporu (5-6-7-8. Sınıflar). Konya: Selçuk Üniversitesi Matbaası.

Demirer, V., Yıldız, D. Ç. ve Sünbül, A. M. (2011). İlköğretim öğrencilerinin bilgisayar ve internet kullanımları ile kitap okuma alışkanlıkları arasındaki ilişki: Konya ili örneği. ilköğretim Online, 10(3), 1028-1036.

Dökmen, Ü. (1994). Okuma becerisi, ilgisi ve alışkanlığı üzerine psikososyal bir araştırma. İstanbul: MEB Yayınları.

Durualp, E., Çiçekoğlu, P. ve Durualp, E. (2013). Sekizinci sınıf öğrencilerinin kitap okumaya yönelik tutumlarının internet ve kitap okuma alışkanlıkları açısından incelenmesi. Uluslararası Türkçe Edebiyat Kültür Eğitim Dergisi, 2(1), 115-132.

Elkatmış, M. (2013). Sınıf öğretmeni adaylarının okuma ilgi ve alışkanlıkları. K. Ü. Kastamonu Eğitim Dergisi, 23(3), 1223-1240.

Geçgel, H. ve Burgul, F. (2009). Eğitim fakültesi öğrencilerinin okuma ilgi alanları. TÜBAV Bilim, 2(3), 341-353.

Gönen, M., Öncü, Ç. E. ve Işıtan, S. (2004). Ilköğretim 5., 6. ve 7. sınıf öğrencilerinin okuma alışkanlıklarının incelenmesi. Milli Eğitim, 164.

Güneş, F. (2007). Türkçe öğretimi ve zihinsel yapılandırma, Ankara: Nobel Yayıncılık.

Gür, T. (2014). Öğretmen adaylarının okuma ve boş zaman değerlendirme alışkanlıkları. Zeitschriff für die Welt Der Türken Journal Of World of Turks, 6(1), 161-180.

Gürcan, H. i. (1999). Okuma alışkanlığı ile kitap yayımcılığının kültürel iletişim ve teknolojisine bağlı sorunları karşısında Türkiye koşulları temelinde bir model önerisi. Eskişehir: T.C. Anadolu Üniversitesi Yayınları No:1113.

Huang, S., Capps, M., Blacklock, J. and Garza, M. (2014). Reading habits of college students in the United States. Reading Pschology, 35, 437-467.

İnan, D. D. (2005). İlköğretim 1. kademe öğrencilerinin okuma alışkanlığının İncelenmesi. Yayınlanmamış yüksek lisans tezi, Marmara Üniversitesi Eğitim Bilimleri Enstitüsü, İstanbul. 
İşcan, A., Arıkan, İ. B. ve Küçükaydın, M. A. (2013). İlköğretim ikinci kademe öğrencilerin kitap okuma alışkanlıkları ve okumaya ilişkin tutumları. Uluslararası Avrasya Sosyal Bilimler Dergisi, 4(11), 1-16.

Karaşahin, M. (2009). Ilköğretim ve ortaöğretim okullarında görev yapan öğretmenlerin okuma kültürlerinin değerlendirilmesi. Milli Eğitim bakanlığı Eğitimi Araştırma ve Geliştirme Dairesi Başkanlığı, Ankara.

Kıbrıs, i. (2010). Çocuk edebiyatı. Ankara: Kök Yayıncılık.

Konan, N. ve Oğuz, V. (2009). Öğretmenlerin okuma alışkanlıkları. XVIII. Ulusal Eğitim Bilimleri Kurultayı, 1-3 Ekim 2009. İzmir: Ege Üniversitesi.

Konan, N. (2013). Illköğretim okulu yöneticilerinin okuma alışkanlıkları. Kuram ve Uygulamada Eğitim Yönetimi [Educational Administration: Theory and Practice], 19(1), 31-59.

Korkmaz, ì. (2007), Üniversite birinci sınıfta okuyan öğrencilerin lise döneminde kitap okuma durumlarının incelenmesi. Eurasian Journal of educational Research, 27, 127-138.

Kurulgan, M. ve Çekerol, G. S. (2008). Öğrencilerin okuma ve kütüphane kullanmaları üzerine bir araştırma. Anadolu Üniversitesi Sosyal Bilimler Dergisi. C.8. s. 237- 258.

Marlow, E. (1992). Helping your child in reading. http://eric.ed.gov/?id=ED345215 adresinden 16.06.2016 tarihinde edinilmiştir.

McCarty, S., Nicastro, J., Spiros, I., and Staley, K. (2001). Increasing recreational reading through the use of read-alouds. http://eric.ed.gov/?id= ED453541 adresinden 08.06.2016 tarihinde alınmıştır.

Mokhtari,K., Reichard, C.A., and Gardner, A. (2009). The Impact of internet and television use on the reading habits and practices of college students. Journal of Adolescent \& Adult Literacy, 52(7), 609-619.

Mugambi, F. N. (2015). Exploring reading habits and academic success in Rural Kenya. International Federation of Library Associations and Institutions, 41(4), 353-363.

Nasser, R. (2013). A Literacy exercise: An Extracurrilular reading Program as an intervention to enrich student reading habits in Qatar. International Journal of Education \& Literacy Studies (IJELS), 1(1), 61-71.

Odabaş, H., Odabaş, Z. Y. ve Polat, C. (2008). Üniversite öğrencilerinin okuma alışkanlığı: Ankara Üniversitesi örneği. Bilgi Dünyası, 9(2), 431-465.

Oyelude, A. A. (2013). Teachers' / students'library use and reading habits in Ido Local Government Area. Ibadani Nigeria. School Libraries Worldwide, 19(2), 69-80.

Özbay, M. (2006). Okuma eğitiminde çevre faktörü. Eurasian Journal of Educational Resarch, 24, 161170.

Özer Özkan, Y. ve Doğan, B. (2013). İlköğretim 8. sınıf öğrencilerinin okuma becerisinin kestirilmesinde etkili olan değişkenlerin belirlenmesi. International Journal of Social Science, 6(4), 667-680.

Pehlivan, A., Serin, O. ve Serin, N. B. (2010). Determining reading interests and habits of candidate teachers (TRNC Sample). Procedia Social and Behavioral Sciences, 9, 869-873.

Rimensberger, N. (2014). Reading is very important but .....:Taking stock of South African student teachers' reading habits. Reading \& Writing, 5(1), 1-9.

Ronkova, J. and Wildova, R. (2015). The Reading matters: Children leadership in the Crezch Republic. Procedia - Social and Behavioral Sciences, 171, $1204-1208$.

Sağlam, M., Suna, Ç. Ve Çengelci, T. (2008). Öğretmen adaylarının okuma alışkanlı̆̆ını etkileyen görüş ve önerileri. Milli Eğitim, 178, s.8-23.

Sangkaeo, S. (1999). Reading habit promotion in Asean Libraries, 65th IFLA Council and General Conference (20-28 August), Tailand: Bangkok. 03.06.2016 tarihinde Eric Database'den alınmıştır.Erişim no:441496.

Saracaloğlu, A. S., Karasakaloğlu, N. ve Aslantürk, E. (2010). Sınıf öğretmeni adaylarının okuma ilgi ve alışkanlıkları arasındaki ilişkilerinin karşılaştııılması (Adnan Menderes ve Uludağ Üniversiteleri Örneği). Ç. Ü. Sosyal Bilimler Enstitüsü Dergisi, 19(3), 457-480.

Sevmez, H. (2009). Türkçe öğretmen adaylarının okuma alışkanlığı ve kütüphane kullanımı üzerine bir inceleme (SÜ Eğitim Fakültesi örneği). Konya: Selçuk üniversitesi Sosyal Bilimler Enstitüsü. 
Smaragdi, U. J. And Jönsson, A. (2006). Book reading in leisure time: long- term changes in young peoples'book reading habits. Scandinavian Journal of Educational Research, 50(5), 519-550.

Stanfield, G. M. (2006). Incentives: The Effect on reading attitude and reading behaviors of third grade students. 16.06.2016 tarihinde http://eric.ed.gov/?id=ED494453 adresinden alınmıştır.

Sukhram, D. P. and Hsu, A. (2012). Developing reading partnership between parents and children: A Reflection on the reading together program. Early Childhood Education, 40, 115-121.

Suna, Ç. (2006). İlköğretim öğrencilerinin okuma ilgi ve alışkanlıklarının Analitik olarak İncelenmesi ve Değerlendirilmesi. Yayımlanmamış yüksek lisans tezi, Anadolu Üniversitesi, Eskişehir.

Şahin, A., Arıcı, A. F., Celepoğlu, A., Dursunoğlu, H., Toz, H., Erdal, K., Turan, L., Yılar, Ö., Kara, R. ve Kılıç, Y. (Ed.). (2011). Eğitim fakülteleri için çocuk edebiyatı. Ankara: Pegem Akademi.

Şahin, A. (2012). illköğretim 4 ve 5. sınıf öğrencilerinin kitap okuma alışkanlıklarının sosyo-ekonomik düzeylerine göre incelenmesi. Türk Eğitim Bilimleri Dergisi, 10(2), 367-388.

Şahin, A., İşcan, A. ve Maden, S. (2009). İlköğretim öğrencilerinin okul kütüphaneleri ve sınıf kitaplıklarını kullanma durumları (Erzurum ili örneği). Atatürk Üniversitesi Sosyal Bilimler Enstitüsü Dergisi, 13(2), 1-12.

Topçuoğlu, F., Yiğit, A. (2014). Çocuklarda okuma kültürünün oluşmasında ailenin etkisi. International Journal of Language Academy, 2(4), 308-322

Uusen, A. and Müürsep, M. (2012). Gender differences in reading habits among boys and girls of basic school in Estonia. Procedia- Social and behavioral Sciences, 69, 1795-1804.

Yağcı, Y. (2007). Çocuk ve gençlerin kitaba ulaşmasındaki köprüler. Türk Kütüphaneciliği, 21(1), 62-71.

Yalman, M., Özkan, E. ve Kutluca, T. (2013). Eğitim fakültesi öğrencilerinin kitap okuma alışkanlıkları üzerine betimsel bir araştırma: Dicle Üniversitesi örneği. Bilgi Dünyası, 14(2), 291-305.

Yaman, H. ve Süğümlü, Ü. (2010). Ilköğretim ikinci kademe öğrencilerinin ders dışı kitap okuma alışkanlıkları. Kastamonu Eğitim Dergisi, 18(1), 291-306.

Yıldırım, A. ve Şimşek, H. (2013). Sosyal bilimlerde nitel araştırma yöntemleri. Ankara, Seçkin Yayıncılık.

Yıldız, M. (2013). Okuma motivasyonu, akıcı okuma ve okuduğunu anlamanın beşinci sınıf öğrencilerinin akademik başarısındaki rolü. Turkish Studies, 8(4), 1461- 1478.

Yılmaz, B. (1990). Okuma alışkanlığı ve Yeni Mahalle illçe Halk Kütüphanesi. Yayınlanmamış yüksek lisans tezi, Hacettepe Üniversitesi Sosyal Bilimler Enstitüsü, Ankara.

Yılmaz, B. (2002). Ankara'daki ilköğretim öğretmenlerinin okuma ve halk kütüphanesi kullanma alışkanlıkları üzerine bir araştırma. Türk Kütüphaneciliği, 16(4), 441-460.

Yılmaz, B. (2012). Okuma alışkanlığının okul başarısına etkisi: Ankara Keçiören Atapark ilköğretim Okulu ögrrencileri üzerine bir araştırma. Prof. Dr. K. Gülbün Baydur'a Armağan İçinde (s. 209-218), Ankara: Hacettepe Üniversitesi Bilgi ve Belge Yönetimi Bölümü.

Yılmaz, B., Köse, E. ve Korkut, Ş. (2009). Hacettepe Üniversitesi ve Bilkent Üniversitesi öğrencilerinin okuma alışkanlıkları üzerine bir araştırma. Türk Kütüphaneciliği, 23(1), 22-51.

Yükselen-İpek, A., Gül-Deretarla, E., Tanju, E. H., Bediz, E., Burçak, F., Dedeoğlu, H., Uysal, H., Veziroğlu, M., Gönen, M., Olgan, R., Ural, S., Işıtan, S., Tepebaş, Ş. ve Bassa, Z. (Ed.). (2013). Çocuk edebiyatı. Ankara: Eğiten Kitap.

\section{Introduction}

\section{Extended Abstract}

Reading; helps people to spend their leisure time, monitor cultural, economic and technological progress, learn new knowledge and succeed in school and social life (Aksaçlıoglu, 2005; Yıldız, 2013). This action; it is perceived as a need by people, and repeated for life, continuously and regularly is called reading habit (Can, Türkyılmaz ve Karadeniz, 2010). This habit, which is gained more quickly in younger children, becomes difficult to gain in later periods unless it is acquired in primary school period (Ronkova ve Wildova, 2015; Sangkaeo, 1999). When the literature is examined; It is seen that there are quantitative studies aimed at determining the factors that prevent reading habits of primary school students. In addition, there are both quantitative and qualitative studies to determine the reading habits of primary school students, but there are no mixed studies including qualitative and 
quantitative studies. The aim of this study is to determine the reading habits of primary school 4th grade students by using mixed method.

\section{Method}

The research is based on the embedded (covering) research pattern of the mixed method. The first part based on quantitative research was attended by 243 students studying in 4th grade in five primary schools in Maçka District of Trabzon province. Quantitative findings were tried to be explained by the qualitative method based on the interviews of 15 parents and 15 teachers selected by the purposeful sampling of these students. In this study, a questionnaire consisting of 25 questions in the quantitative part and the semi-structured interview and interview form, which are frequently used in the qualitative research methods, were used in the qualitative part. . The data obtained in the quantitative dimension of the research were analyzed with the SPSS 23.0 program, the analysis results are shown in frequency and percentage. In the qualitative dimension of the research, the data obtained through 7 semi-structured interviews, 8 teachers and 15 parents interview forms were analyzed with descriptive analysis.

\section{Result and Discussion}

At the end of the study, it was concluded that primary school students did not read a sufficient number of books despite reading books regularly every day. Students with 10 or fewer books apart from the textbook were found to read 6-10 books a year. It is concluded that the type of these books they read the most is story and the subject is adventure. It appears that students paying attention to the subject most while choosing buy the books they are to read with their parents. It has been revealed that apart from books, students who use the library to buy stories and novels prefer reading magazines, and television prevents them from reading. At the end of the interviews, teachers who show parents as not being models to their children for not liking reading stated that they arranged a reading time for their students so that they can develop a reading habit.

The teachers stated that they created a class library from the books they bought by selecting them together with their students in order to provide books to those who do not use the school library enough. They also stated that they could not benefit from the school library sufficiently because the curriculum was intense.

The parents stated that their children read regularly in order to improve themselves. The parents, who stated that they had created a library in their home with the books they bought, pointed out that they could not go to the library because there was not a regular one in their region. 